\title{
Studies on the Identification of Tobacco Alkaloids, their Mammalian Metabolites and Related Compounds by Gas Chromatography - Mass Spectrometry*
}

by

Ake Pilotti and Curt R. Enzell

Swedish Tobacco Company, Research Department, Stockholm, Sweden

Herbert McKennis, Jr., and Edward R. Bowman

Department of Pharmacology, Medical College of Virginia, Richmond, Virginia, U.S.A.

and

Eva Dufva and Bo Holmstedt

Department of Toxicology, Swedish Medical Research Council, Karolinska Institutet, Stockholm, Sweden

\section{INTRODUCTION}

Substantial dhemical changes are known to occur in the pyridine and pyrrolidine rings of nicotine, including almost complete degradation of the pyrrolidine ring, during fermentation and storage of tobacco $(x-3)$ and during mammalian metabolism (4). Although some of the known routes in the mammalian metabolism of nicotine, including that in man, are well established (Schemes $1 \mathrm{a}$ and $\mathrm{xb}$ ), further inquiry into the detection and quantification of the numerous alkaloids involved was deemed important. A systematic gas dhromatographic-mass spectrometric (GC-MS) study of a series of established nicotine metabolites was therefore undertaken to provide a basis for sudh an investigation. The results of these studies and of preliminary GC-MS experiments on the determination of nicotine in plasma, accomplished with the aid of multiple ion detection (MID) and deuterated nicotine as an internal standard, are here reported.

\section{EXPERIMENTAL}

\section{Compounds}

The compounds studied were synthesized or isolated as indicated by the references in Table $x$. Of these compounds, the acids (XVIII, XX, XXII, XXVII and $X X I X)$ possess less attractive gas dromatographic properties and in order to circumvent this problem the

\footnotetext{
- Presented at the Nicotine and Carbon Monoride Symposium, Tobacco and Healsh Research Institute, University of Kentudy, Lexington, Kentuck, 17th and 18th November, 1975.
}

corresponding methyl esters (XIX, XXI, XXIII, XXVIII, $X X X)$ were also prepared $\left(\mathrm{CH}_{2} \mathrm{~N}_{2}\right)$ and examined.

\section{Gas Chromatography and Mass Spectrometry Conditions}

GC-MS employing capillary columns was carried out, unless otherwise indicated, on an LKB 2091 mass spectrometer (ion source temperature: $270^{\circ} \mathrm{C}$, electron energy: $70 \mathrm{eV}$ ) linked to a Varian 2700 instrument equipped with a capillary injector, a device for introduction of make-up gas, a splitter, and a flame-ionization detector. Helium was used as carrier gas in these determinations.

Mass spectra of the less volatile compounds were recorded using the direct inlet system.

GC was performed on a Varian 1700 or 2700 instrument, equipped with a flame-ionization detector. The temperature of the injector and the detector was maintained at $230^{\circ} \mathrm{C}$. The packed glass columns were [i] $3 \%$ SE 30 , [ii] $5 \%$ SE 52 , and [iii] $8 \%$ Carbowax $20 \mathrm{M}$ and $2 \%$ potassium hydroxide - all on Gas Chrom $Q$ (100/120 mesh). The nitrogen flow rate was $30 \mathrm{ml} / \mathrm{min}$.

High resolution GC was performed on the Varian 2700 instrument equipped with a capillary injector using either a glass capillary column $(33 \mathrm{~m}, \mathrm{i}$. d. $0.4 \mathrm{~mm}$ ) coated with Emulphor-O or a column $(9.6 \mathrm{~m}, \mathrm{i}$. d. 0.2 $\mathrm{mm}$ ) coated with OV-101. The nitrogen flow rates were 2.5 and $1.0 \mathrm{ml} / \mathrm{min}$ respectively, and the samples were injected on the capillary columns using a split ratio of 1:30.

The separations on the packed columns were carried out under isothermal conditions, while those on the capillary columns were performed using temperature programming. After 3 minutes at $125^{\circ} \mathrm{C}$, the temperature was increased by $6^{\circ}$ per minute to $200^{\circ} \mathrm{C}$. 
Scheme 1a. Abridged scheme for the mammalian metabolism of nicotine.<smiles>CC1CCCC1c1cccnc1</smiles>

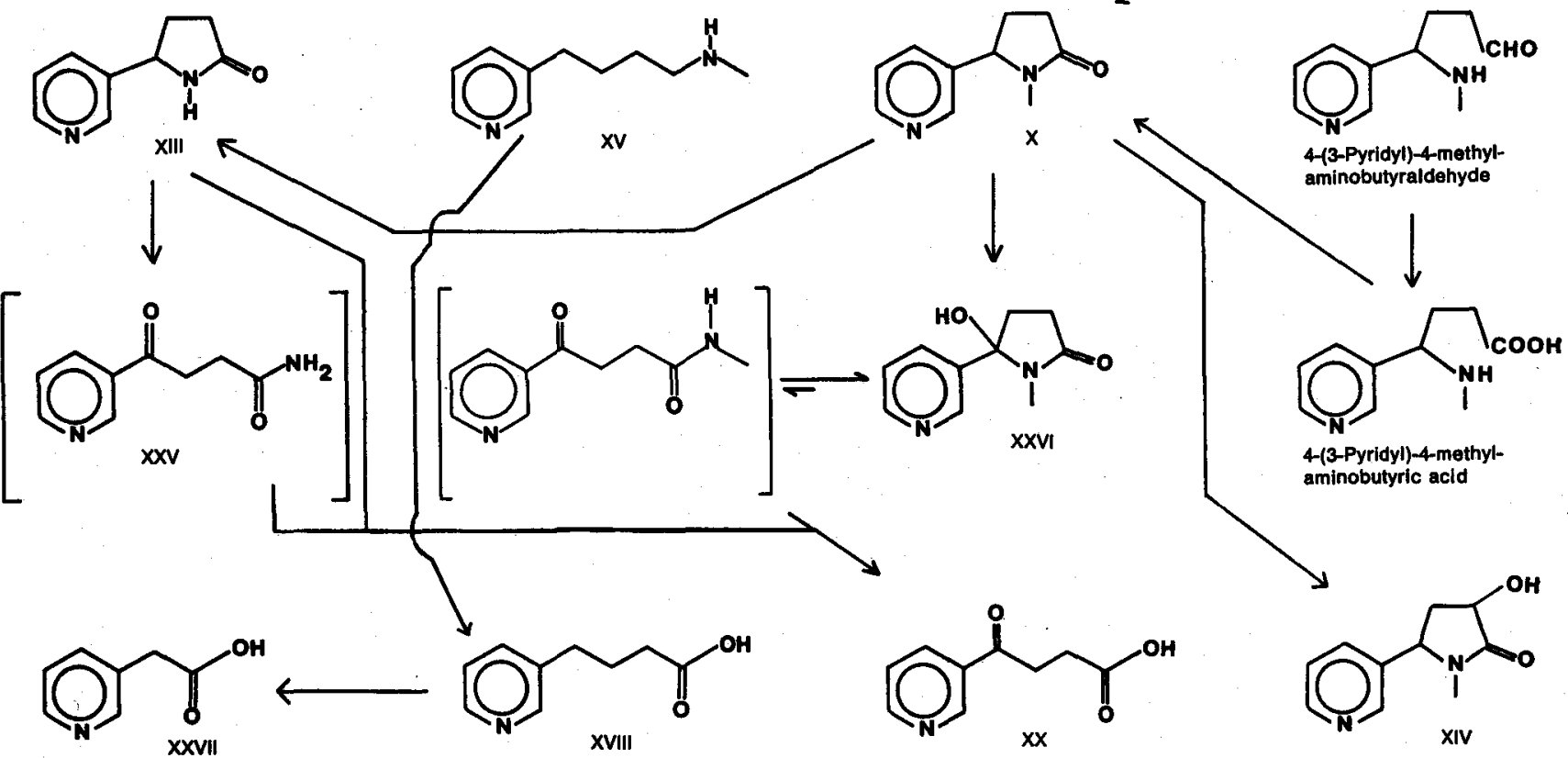

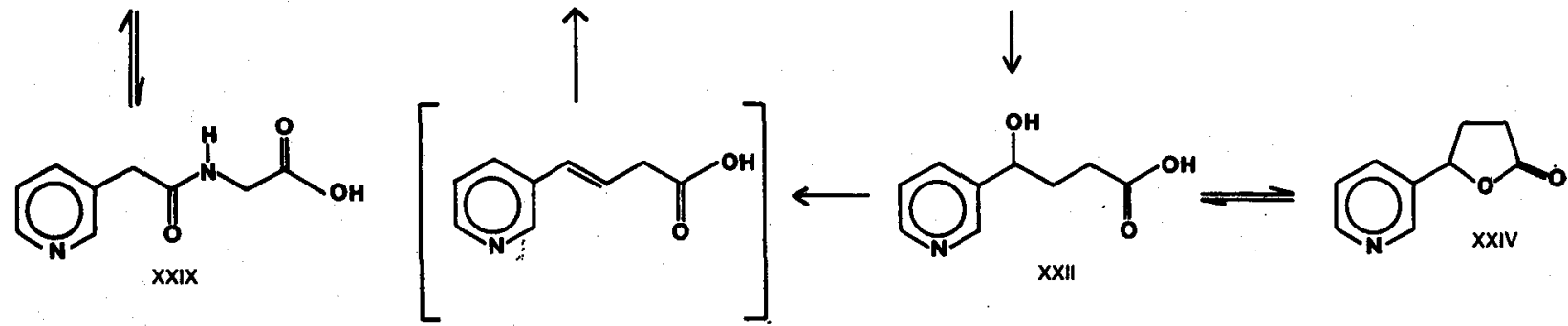

4-(3-Pyridyl)-3-cis/transbutenoic acid

Scheme 1b. Abridged scheme showing ions and N-oxides implied in the mammallan metabollsm of nicotine.<smiles>C[N+]1([O-])CCCC1c1cccnc1</smiles>

III<smiles>C=C=C</smiles>

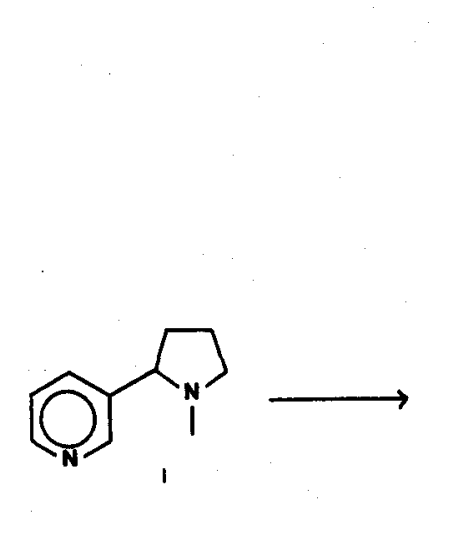<smiles>[X]C1C(=O)CCC1c1cccnc1</smiles><smiles>Cc1cccc(C2CCCN2C)c1</smiles>

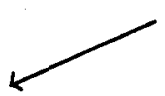


Determination of Nicotine in Blood Plasma by Mass Fragmentography

To samples of heparin-treated blood plasma ( $x \mathrm{ml}$ ) obtained from male smokers, $50 \mathrm{ng}$ of 5-d -S-nicotine (5) (in I $\mathrm{ml}$ of water) was added as an internal standard. The sample was then adjusted to $\mathrm{pH}$ xo by addition of $0.05 \mathrm{ml}$ of $\mathrm{N} \mathrm{NaOH}$ and extracted twice with $5 \mathrm{ml}$ of $\mathrm{n}$-hexane by mechanical shaking for 10 min. After centrifugation of the mixture, an aliquot $(9 \mathrm{ml})$ of the combined hexane solutions was removed and concentrated under a stream of argon to a small residue which was adjusted to $25 \mu$ by addition of methanol. A sample ( 1 ul) was removed for injection into an LKB gooo instrument equipped with a glass column $(1.7 \mathrm{~m}, \mathrm{i} . \mathrm{d} .1 \mathrm{~mm})$ packed with $8 \%$ Carbowax $20 \mathrm{M}(2 \% \mathrm{KOH})$ on Gas-Chrom $\mathrm{Q}$ (100/120 mesh) : helium carrier gas, $30 \mathrm{ml} / \mathrm{min}$; injection port, $220^{\circ} \mathrm{C}$; column oven, $142^{\circ} \mathrm{C}$; separator, $255^{\circ} \mathrm{C}$. The data system and instrumental control have been described previously (6).

\section{RESULTS AND DISCUSSION}

Prior to the present study, many gas chromatographic methods have been reported for the separation of nicotine and cotinine $(7-10,57)$. These tobacco constituents, of which nicotine is partly converted to cotinine during fermentation and storage of tobacco (z), are two of the most readily detectable compounds in urine and have been employed as possible indicators of exposure to tobacco smoke. Moreover, cotinine, like nicotine, is pharmacologically active and is known to lower the blood pressure in experimental animals ( $x x$ ) and to leave the blood at a much slower rate than nicotine after cessation of smoking (12-15). Assays of the cotinine content of biological fluids are receiving increased emphasis, but the many studies in which gas chromatography alone has been used for the determination of cotinine have not consistently mentioned necessary controls or specified conditions which would exclude the possible confusion of this compound with other bases such as norcotinine (XIII), hydroxycotinine (XIV) and allohydroxycotinine (XXVI). Since these mammalian metabolites of nicotine most often accompany cotinine in solvent extractions preceding gas chromatographic determinations, this constitutes a general problem, which was solved in the present study by the development of adequate conditions for gas chromatographic-mass spectrometric determinations. In particular, the use of capillary columns in combination with multiple ion detection (MID) employing a deuterated form of the compound under consideration as an internal standard is an advantage, since this procedure allows specific ion quantification of a number of nicotine metabolites at levels present in biological fluids.

The compounds covered in the present study are detailed in Table 1 , which also includes relevant $\mathrm{GC}$. data; the corresponding mass spectra are given in Figures 1 to 30.

Since reasonable stability or storage qualities were deemed a prerequisite for including a compound in the present study, 4-(3-pyridyl)-4-methylaminobutyraldehyde, which is notorious for its instability, was excluded. This compound has a designated intermediary function in the mammalian degradation of nicotine $(42,43)$, especially when it is in the isomeric ring form $5^{\prime}$-hydroxynicotine or the related form nicotine- $\Delta^{1}\left(b^{\prime}\right)$ iminium ion (43). Myosmine (VI), B-nicotyrine (VII), anabasine (VIII) and methylanabasine (IX) were included, although of these four bases only $\beta$-nicotyrine has been implied - but not fully characterised (44) as a nicotine metabolite. These minor tobacco alkaloids were included because of the increasing interest in the biological and pharmacological effects of the compounds and also because of various similarities in the mass spectral data. As can be seen, nicotine (Fig. xa) and anabasine (Fig. 8) display molecular and base peaks at identical mass numbers, and cotinine (Fig. 10) and methylanabasine (Fig. 9) are also a comparable pair. Although never shown to be a nicotine metabolite, nicotine-1, $\mathbf{1}$ '-dioxide (IV) was deemed of sufficient interest to be examined since both pyridine (25) and pyrrolidine (45) $\mathrm{N}$-oxides have established roles in the metabolism of nicotine. 4-(3-Pyridyl)-4-oxobutyramide (XXV) was included because it has a possible intermediary function between norcotinine and 4-(3-pyridyl)4-oxobutyric acid in the metabolism of nicotine.

Additionally, cis- and trans-metanicotine (30) were studied since metanicotine (46) may theoretically arise as a precursor in the mammalian metabolism of nicotine to dihydrometanicotine, 4-(3-pyridyl)-N-methylbutylamine (47). Metanicotine has also been reported as a tobacco alkaloid $(48,49)$, as a possible bacterial metabolite of nicotine (50) and as a component of cigarette smoke $(51,52)$, possibly arising through pyrolysis of nicotine (53). However, neither the geometry nor the relative distribution of the two isomers of metanicotine as they occur in nature or as a pyrolysis product of nicotine has been recorded. The two isomers are easily separated on an Emulphor- $\mathrm{O}$ capillary column, but the mass spectrometer cannot readily be used as the sole means of distinction, as the mass spectra of these isomers (Figures 16 and 17) are almost identical.

Of the present compounds (Table $I$ ), neither the more acidic metabolites of nicotine (XVIII, XX, XXII, XXVII, $X X I X)$ nor the thermally unstable quaternary ammonium compounds (II, XI) and N-oxides (III, IV, XII) could be studied by the GC-MS directly, although nicotine- $\mathrm{I}^{\prime}$-oxide could be chromatographed on the Emulphor-O capillary column without complete degradation. The quaternary ammonium compounds were examined only by the use of the direct inlet system, while the acids were converted to the methyl esters, for many of which appropriate GC-conditions have already been described (37). In preparing the esters, diazomethane was, however, preferred to the methanolsulfuric acid previously used in the esterification, since a better ratio of methyl 4-(3-pyridyl)-4-hydroxybutyrate to the undesired 5-(3-pyridyl)tetrahydrofuran-2-one was obtained with diazomethane. 
Table 1. Gas chromatographlc data.

\begin{tabular}{|c|c|c|c|c|c|}
\hline \multicolumn{2}{|r|}{ Compound } & \multicolumn{2}{|c|}{ Retention times } & \multirow{2}{*}{$\frac{\begin{array}{c}\text { Mode of } \\
\text { recording MS }\end{array}}{\text { GC-MS }}$} & \multirow{2}{*}{$\begin{array}{l}\text { References } \\
5,16\end{array}$} \\
\hline I $\mathbf{a}$ & S-(-)-Nicotine & $\begin{array}{l}6.0 / 85^{\circ} \mathrm{C} \\
5.3 / 135^{\circ} \mathrm{C} \\
5.0\end{array}$ & $\begin{array}{l}\text { A } \\
\text { B } \\
\text { C }\end{array}$ & & \\
\hline I b & 5-dz-S-(-)-Nicotine & $4.7 / 142^{\circ} \mathrm{C}$ & B & GC-MS & 5 \\
\hline II & S-(-)-Nicotine Isomethlodide hydroiodide & & & Direct probe & 17 \\
\hline III & S-(-)-Nicotine-1'-oxidea & 10.6 & $\mathbf{C b}$ & Direct probe & $18,19,20$ \\
\hline IV & S-(-)-Nicotine-1,1'-dioxidea & & & Direct probe & 18,20 \\
\hline V & S- $(-)-$ Nornicotine & $\begin{array}{l}9.0 / 90^{\circ} \mathrm{C} \\
10.7\end{array}$ & $\begin{array}{l}A \\
C\end{array}$ & GC-MS & 5 \\
\hline VI & Myosmine & $5.9 / 90^{\circ} \mathrm{C}$ & A & GC-MS & 5 \\
\hline VII & B-Nicotyrine & $\begin{array}{l}5.0 / 100^{\circ} \mathrm{C} \\
13.2\end{array}$ & $\begin{array}{l}\text { A } \\
\text { C }\end{array}$ & GC-MS & 21 \\
\hline VIII & S-(-)-Anabasine & $\begin{array}{l}5.6 / 100^{\circ} \mathrm{C} \\
10.8\end{array}$ & $\begin{array}{l}A \\
C\end{array}$ & GC-MS & 5 \\
\hline $\mathbf{I X}$ & S-(-)-Methylanabasine & $\begin{array}{l}4.5 / 100^{\circ} \mathrm{C} \\
5.3\end{array}$ & $\begin{array}{l}\mathrm{A} \\
\mathrm{C}\end{array}$ & GC-MS & 22 \\
\hline$x$ & S-(-)-Cotinine & $\begin{array}{l}5.8 / 130^{\circ} \mathrm{C} \\
7.0 / 213^{\circ} \mathrm{C} \\
23.2 \\
3.2 / 170^{\circ} \mathrm{C} \\
5.4\end{array}$ & $\begin{array}{l}A \\
B \\
C \\
D \\
E\end{array}$ & GC-MS & 5,23 \\
\hline $\mathbf{X I}$ & S-(-)-Cotinine methiodide & & & Direct probe & 17 \\
\hline XII & S-(-)-Cotinine-1-oxide & ' & & Direct probe & 24,25 \\
\hline XIII & S-(-)-Norcotinine & $\begin{array}{l}5.9 / 135^{\circ} \mathrm{C} \\
10.9 / 265^{\circ} \mathrm{C} \\
4.4 / 170^{\circ} \mathrm{C}\end{array}$ & $\begin{array}{l}\text { A } \\
\text { B } \\
\text { D }\end{array}$ & GC-MS & 26,27 \\
\hline XIV & (5S, 3 R)-3-Hydroxycotinine & $\begin{array}{l}5.7 / 140^{\circ} \mathrm{C} \\
4.6 / 170^{\circ} \mathrm{C}\end{array}$ & $\begin{array}{l}\mathbf{A} \\
\mathbf{D}\end{array}$ & GC-MS & 25,28 \\
\hline $\mathrm{XV}$ & Dihydrometanicotine & $\begin{array}{l}4.9 / 105^{\circ} \mathrm{C} \\
9.9\end{array}$ & $\begin{array}{l}\text { A } \\
\text { C }\end{array}$ & GC-MS & 29 \\
\hline $\mathrm{XVI}$ & trans-Metanicotine & $\begin{array}{l}4.3 / 110^{\circ} \mathrm{C} \\
13.5\end{array}$ & $\begin{array}{l}A \\
C\end{array}$ & GC-MS & 30 \\
\hline XVII & cis-Metanicotine & $\begin{array}{l}3.8 / 110^{\circ} \mathrm{C} \\
11.2\end{array}$ & $\begin{array}{l}A \\
C\end{array}$ & GC-MS & 30 \\
\hline XVIII & 4-(3-Pyridyi)butyric acid & & & Direct probe & 31 \\
\hline $\mathrm{XIX}$ & Methyl 4-(3-pyridyl)butyrate & $\begin{array}{l}6.8 / 95^{\circ} \mathrm{C} \\
12.6\end{array}$ & $\begin{array}{l}A \\
C\end{array}$ & GC-MS & 32,33 \\
\hline $\mathbf{X X}$ & 4-(3-Pyridyl)-4-oxobutyric acid & & & Direct probe & 34 \\
\hline $\mathbf{X X I}$ & Methyl 4-(3-pyridyl)-4-oxobutyrate & $\begin{array}{l}4.3 / 125^{\circ} \mathrm{C} \\
19.1\end{array}$ & $\begin{array}{l}\text { A } \\
\text { C }\end{array}$ & GC-MS & 32 \\
\hline XXII & 4-(3-Pyridyl)-4-hydroxybutyric acidc & & & Direct probe & 32,34 \\
\hline XXIII & Methyl 4-(3-pyrldyl)-4-hydroxybutyratec & $\begin{array}{l}5.9 / 140^{\circ} \mathrm{C} \\
19.0\end{array}$ & $\begin{array}{l}\text { A } \\
\text { C }\end{array}$ & GC-MS & 32 \\
\hline XXIV & 5-(3-Pyridyl)tetrahydrofuran-2-onec & $\begin{array}{l}6.0 / 140^{\circ} \mathrm{C} \\
23.2 \\
5.8\end{array}$ & $\begin{array}{l}A \\
C \\
E\end{array}$ & GC-MS & 32,34 \\
\hline$X X V$ & 4-(3-Pyridyl)-4-oxobutyramide & $5.7 / 145^{\circ} \mathrm{C}$ & A & GC-MS & 35 \\
\hline$\overline{X X V I}$ & Allohydroxycotininec & $\begin{array}{l}5.6 / 140^{\circ} \mathrm{C} \\
6.8 / 213^{\circ} \mathrm{C} \\
3.0 / 170^{\circ} \mathrm{C}\end{array}$ & $\begin{array}{l}\text { A } \\
\text { B } \\
\text { D }\end{array}$ & GC-MS & $25,36,37$ \\
\hline
\end{tabular}




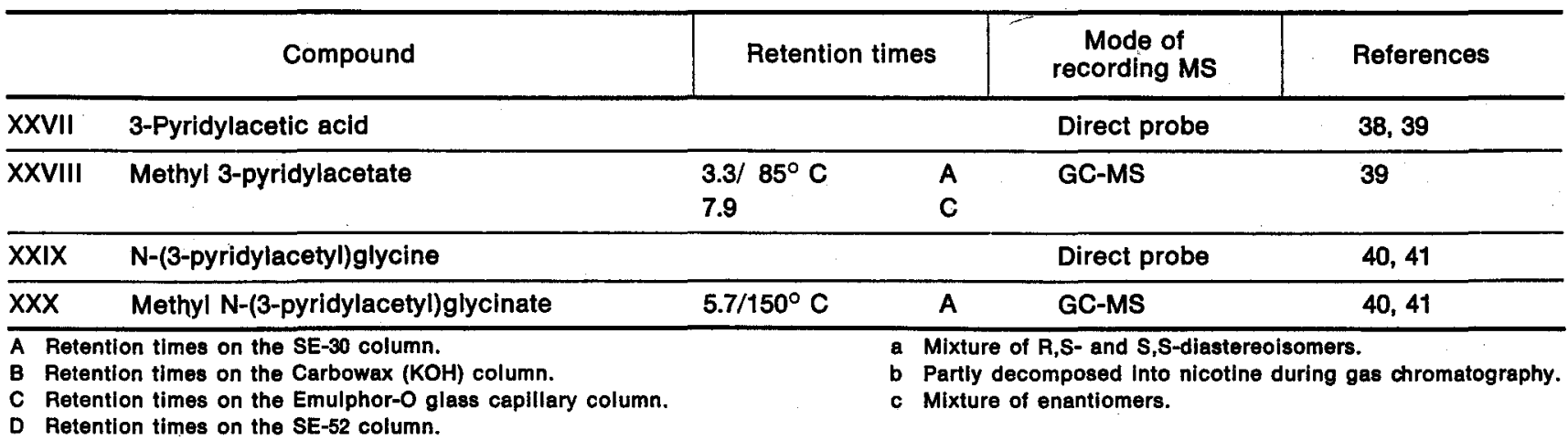

E Retention times on the OV-101 glass capillary column.

Allohydroxycotinine (XXVI), although weakly acidic and amphoteric, can be separated from the above acidic metabolites of nicotine by extraction with organic solvents and can even be chromatographed on a basic Carbowax column. However, it emerges simultaneously with cotinine from all of the three packed columns used in the present investigation, a problem which can easily be circumvented by employing the MID technique and monitoring mass numbers 98 for cotinine, 100 for 3-d2-cotinine (5) and 192 for allohydroxycotinine. Refocusing on other masses further enhances the reliability of the quantifications.

Similarly, the emergence of norcotinine (XIII) and 3-hydroxycotinine (XIV) coincided on the SE-30 and SE-52 columns but focusing on $m / e 162\left(M^{+}\right)$for norcotinine, on $\mathrm{m} / \mathrm{e} 192\left(\mathrm{M}^{+}\right)$for 3-hydroxycotinine and on the corresponding ions of suitable labelled internal standards would allow adequate quantification.

It may also be noted that cotinine and 5-(3-pyridyl)tetrahydrofuran-2-one could not be separated on the Emulphor-O glass capillary column. These compounds were, however, easily separated on an OV-101 capillary column, which makes their determination possible in the event that a mass spectrometer is not available.

The mass spectra of nicotine, nornicotine, cotinine, anabasine, myosmine $(5,16)$, nicotine- 1,1 '-dioxide (18) and nicotine-1'-oxide (18), of which both cis and trans forms are generated metabolically from S-(-)-nicotine, have previously been studied in some detail. Moreover, mass spectrometric data have been presented for allohydroxycotinine, 5-(3-pyridyl)-5-hydroxy-1-methyl-2pyrrolidone (25). In the present study, the spectra of allohydroxycotinine obtained by GC-MS and by direct inlet mass spectrometry were similar to those previously reported. The spectra do not, however, appear to provide direct evidence on the possible contributions of the ring (pyrrolidone) and open chain (ketoamide) tautomeric forms (4) of the compounds.

The GC data presented in this study form the basis for the development of reliable quantitative estimations of nicotine, its metabolites and related compounds. The use of a mass spectrometer and especially multiple ion detection further facilitates these estimations and may ultimately be of significance in checking various other quantification methods such as radioimmunoassays that are now being employed to some extent for the de- termination of nicotine and its metabolites $(14,15,54)$. Prior to the present investigation mass spectrometry has been used in only one study to confirm the identity of the nicotine peak in quantitative GC (9).

To illustrate the potentialities of GC-MS determinations of tobacco alkaloids in biological fluids along lines previously described for many other compounds (55), blood plasma was obtained from two smokers. In these preliminary experiments, deuterated nicotine was added as an internal standard to the heparintreated venous blood, and an $n$-hexane extract of the plasma was subjected to GC-MS analysis.

The plasma from a heavy smoker (25 years of age, weight: $67 \mathrm{~kg}$, average daily consumption: 20 cigarettes), who had just smoked four high-level nicotine cigarettes in 20 minutes, showed a nicotine level of $95 \mathrm{ng} / \mathrm{ml}$ as calculated from the relative peak heights of the base peak of nicotine at 84 mass units and the base peak of deuterated nicotine at 86 mass units (Fig. Ia). This very high nicotine level may be related to the fact that the subject inhaled very deeply while he smoked the four cigarettes. The plasma from the other smoker (44 years of age, weight: $80 \mathrm{~kg}$, average daily consumption: 20 cigarettes), who had not smoked for 15 minutes before the blood sample was taken, contained nicotine at the level of $26 \mathrm{ng} / \mathrm{ml}$ (Fig. Ib). Both smokers used their own cigarette brands and the latter subject conformed to his regular smoking habits. The identity of the nicotine in the plasma samples was ascertained by the retention time, by recording the entire mass spectrum, and by refocusing on other mass units in the nicotine spectrum.

Further biological applications as well as mechanistic studies on the mass spectrometric fragmentation of the various alkaloids will be discussed elsewhere.

\section{SUMMARY}

Various pyridine compounds, either identified or implied as intermediates in the mammalian metabolism of nicotine or present in tobacco or tobacco smoke, have been studied by gas chromatography-mass spectrometry. Spectral and gas chromatographic data for these compounds, which provide a basis for further studies of pyridine compounds in plant and animal tissue, are given. The utility of these data in studies on nicotine 
and its metabolites in body fuids from humans is illustrated by a determination of nicotine in the plasma from two smokers using quantitative mass fragmentography with the aid of deuterated nicotine.

\section{ZUSAMMENFASSUNG}

Verschiedene Pyridinverbindungen, die entweder als Zwischenprodukte im Nikotinstoff wechsel von Säugetieren identifiziert oder vermutet wurden oder im Tabak bzw. Tabakrauch vorhanden sind, wurden mit Hilfe von Gaschromatographie und damit gekoppelter Massenspektrometrie untersucht. Die massenspektrometrischen und gaschromatographischen Daten dieser Verbindungen, welche eine Grundlage für weitere Untersuchungen der Pyridinverbindungen in pflanzlichen und tierischen Geweben bieten, werden dargelegt. Die Verwendbarkeit dieser Daten bei der Untersuchung des Nikotins und seiner Metaboliten in den Körperflüssigkeiten des Menschen wird gezeigt anhand der Bestimmung des Nikotins im Blutplasma von zwei Rauchern unter Benutzung von deuteriertem Nikotin und der Verwendung quantitativer Massenspektrometrie.

\section{RESUME}

On a étudié à l'aide de chromatographie en phase gazeuse couplée à un spectromètre de masse différents composés pyridiniques, qui sont identifiés ou impliqués comme intermédiaires dans le métabolisme de la nicotine chez les mammifères ou présents dans le tabac ou la fumée de tabac. On a donné les résultats de spectrométrie et de chromatographie en phase gazeuse de ces composés, résultats sur lesquels peuvent s'appuyer des recherches plus avancées sur les composés pyridiniques dans le tissu végétal ou animal. On a illustré l'utilité de ces résultats par l'étude de la nicotine et de ses métabolites dans les liquides humains: on a déterminé la nicotine dans le plasma de deux fumeurs, par spectrométrie de masse quantitative à l'aide de nicotine marquée au deutérium.

\section{REFERENCES}

1. Frankenburg, W. G., A. M. Gottscho, and A. A. Vaitekunas: Proc. First Internat. Sci. Tobacco Cong. 1955, Paris-Bergerac, vol. 2, 419.

2. Frankenburg, W. G., and A. A. Vaitekunas: J. Amer. Chem. Soc. 79 (1957) 149.

3. Frankenburg, W. G., A. M. Gottscho, and A. A. Vaitekunas: Abstracts of papers, gth Tobacco Chemists' Research Conference, Raleigh, N. C., U.S.A., 1955.

4. McKennis, H., Jr.: Disposition and fate of nicotine in animals, in: Tobacco alkaloids and related compounds, ed. by U. S. von Euler; Pergamon Press, Oxford, 1965, p. 346.

5. Duffield, A. M., H. Budzikiewicz, and C. Djerassi: J. Amer. Chem. Soc. 87 (1965) 2926.

6. Elkin, K., L. Pierrou, U. G. Ahlborg, B. Holmstedt, and J.-E. Lindgren: J. Chromatogr. 81 (1973) 47.
7. Beckett, A. M., and E. J. Triggs: Nature 21x (1966) 1415.

8. Isaac, P. F., and M. J. Rand: Nature 236 (1972) 308.

9. Falkman, S. E., I. E. Burrows, R. A. Lundgren, and B. F. J. Page: Analyst 100 (1975) 99.

10. Feyerabend, $C_{\text {., }}$ T. Levitt, and M. A. H. Russell: J. Pharm. Pharmac. 27 (1975) 434.

11. Borzelleca, J. F., E. R. Bowman, and H. McKennis, Jr.: J. Pharmacol. Exp. Therap. 137 (1962) 313.

12. Isaac, P. F., and M. J. Rand: Eur. J. Pharmacol. 8 (1969) 264 .

13. Burrows, I. E., P. J. Corp, G. C. Jadksen, and B. F. Page: Analyst 96 (1971) 81.

14. Langone, J. J., H. B. Gjika, and H. van Vunakis: Biochemistry 12 (1973) 5025.

15. Haines, C. F., Jr., D. K. Mahajan, D. Miljkovik, M. Miljković, and E. S. Vesell: Clin. Pharmacol. Ther. 16 (1974) 1083.

16. Liehr, J. G., P. Schulze, and W. J. Richter: Org. Mass Spectrom. 7 (1973) 45.

17. McKennis, H., Jr., L. B. Turmbull, and E. R. Bowman: J. Biol. Chem. 238 (1963) 719.

18. Schüller, D., and H.-P. Harke: Org. Mass Spectrom. 7 (1973) 839.

19. Papadopoulos, N. M.: Arch. Biochem. Biophys. 106 (1964) 182.

20. Craig, J. C., and K. K. Purushothaman: J. Org. Chem. 35 (x97o) $x 721$.

21. Clemo, G. R.: Tetrahedron 11 (1960) 11.

22. Rodgman, A., L. C. Cook, and S. S. Mims: J. Org. Chem. 26 (1961) 497.

23. Bowman, E. R., and H. McKennis, Jr.: Biochem. Prep. 10 (1963) 36.

24. Dagne, E., and N. Castagnoli, Jr.: J. Med. Chem. 15 (1972) 840 .

25. Dagne, E.: Biotransformation studies on S-(-)-cotinine; Doctorial Thesis, University of California, San Francisco, 1972.

26. Wada, E., E. R. Bowman, L. B. Turnbull, and H. McKennis, Jr.: J. Med. Pharm. 4 (1961) 21.

27. Harke, H.-P., D. Schüller, B. Frahm, and A. Mauch: Res. Commun. Chem. Pathol. Pharmacol. 9 (1974) 595.

28. McKennis, H., Jr., L. B. Turnbull, E. R. Bowman, and E. Tamaki: J. Org. Chem, 28 (1963) 383.

29. Meadham, R. H., Jr., E. R. Bowman, and H. McKennis, Jr.: J. Biol. Chem. 247 (1972) go2.

3o. Sprouse, C. T., R. H. Meadham, Jr., E. R. Bowman, and $\mathrm{H}$. McKennis, Jr.: Abstracts of papers, Coresta/26th TCRC Joint Conference, Williamsburg, Va., U.S.A., October 1972.

31. McKennis, H., Jr., E. R. Bowman, and L. B. Turnbull: J. Amer. Chem. Soc. 82 (x960) 3974.

32. McKennis, H., Jr., E. R. Bowman, and M. S. Dar: Virg. J. Sci. 18 (1967) 13.

33. Schwartz, S. L.., and H. McKennis, Jr.: J. Biol. Chem. 238 (1963) 1807.

34. McKennis, H., Jr., S. L. Schwartz, L. B. Turnbull, E. Tamaki, and E. R. Bowman: J. Biol. Chem. 239 (x964) $398 x$. 
35. McKennis, H., Jr., E. R. Bowman, and L. D. Quin: Unpublished results.

36. Brandänge, S., L. Lindblom, A. Pilotti, and T. Nishida : to be published.

37. McKennis, H., Jr., E. R. Bowman, L. D. Quin, and R. C. Denney: Abstracts of the American Chemical Society Meeting, New York, 1966.

38. Malan, R. L., and P. M. Dean: J. Amer. Chem. Soc. 69 (1947) 1797.

39. McKennis, H., Jr., E. R. Bowman, and L. B. Turnbull: Proc. Soc. Exp. Biol. Med. 107. (1961) 145.

40. Bowman, E. R., R. S. L. Chang, C. T. Sprouse, and H. McKennis, Jr.: Abstracts of papers, 27th Tobacco Chemists' Research Conference, WinstonSalem, North Carolina, U.S.A., 1973.

41. Bowman, E. R., R. S. L. Chang, C. T. Sprouse, and H. McKennis, Jr.: Unpublished results.

42. Hucker, H. B., J. R. Gilette, and B. B. Brodie: J. Pharmacol. Exp. Therap. 129 (1960) 94.

43. Murphy, P. J.: J. Biol. Chem. 248 (1973) 2796.

44. Werle, E., and A. Meyer: Biochem. Z. 321 (1950) 221.

45. Booth, J., and E. Boyland: Biochem. Pharmac. 19 (1970) 733 .

46. Rich, M. M., R. H. Meacham, Jr., E. R. Bowman, and H. McKennis, Jr.: Virg. J. Sci. 21 (1970) 147.

47. Truhaut, R., and M. de Clerq: Bull. Soc. Chim. Biol. 41 (1959) 1693.

48. Wahl, R.: Bundesanstalt für Tabakforschung Forchheim/Karlsruhe, Sonderheft Tabak-Forschung, 1953, 36.

49. Parups, E. V.: Tobacco Science 4 (1960) 163.

50. Wenusch, A.: Lebensmittel-Unters. Forsch. 86 (1943) 251.

51. Neurath, G., M. Duinger, J. Gewe, W. Lüttich, and H. Wichern: Beitr. Tabakforsch. 3 (Ig66) 563.

52. Dymidky, M., and R. L. Stedman: Phytochem. 6 (1967) 1025.

53. Jarboe, C. H., and C. J. Rosene: J. Chem. Soc. 1961, 2455.
54. Matsukura, S., N. Sakamoto, H. Imura, H. Matsuyama, T.-Tamada, T. Ishiguro, and H. Muranaka: Biochem. Biophys. Res. Comm. 64 (1975) 574.

55. Holmstedt, B., and J.-E. Lindgren: In: The poisoned patient - The role of the laboratory; Ciba Foundation Symposium 26 (new series), 1974, p. 105.

56. Brandänge, S., and L. Lindblom: Acta Chem. Scand. Ser. B 29 (1975) 93.

57. Dumas, C., R. Badré, A. Viala, J.-P. Cano, and R. Guillerm: Eur. J. Toxicol. 8 (1975) 280.

\section{Acknowledgements}

The authors are grateful to the Council for Tobacco Research - U.S.A., the American Medical Association Education and Research Foundation, the National Institutes of Health (RG-1Ro1 NSo8966), the American Tobacco Company, and the Swedish Tobacco Company for financial support.

This research has been supported by the following grants to the Department of Toxicology, Karolinska Institutet: the Swedish Medical Research Council (B76-04X-00199-12B， B76-25X-04041-04A， B76-70E3743-04A), the National Institute of Mental Health (Grant $M H$ 12007), the Wallenberg Foundation, and the Tri-Centennial Fund of the Bank of Sweden (68/53:1).

Grateful appreciation is also expressed to Mrs. P. Bejbom for valuable technical assistance, to Dr. C. T. Sprouse for preparation of some of the compounds, and to Dr. J.-E. Lindgren for performing the mass fragnientography.

The authors' address:

Swedish Tobacco Company, Research Department, P. O. Box 17007, S-10462 Stockholm, Sweden.

Department of Pharmacology, Medical College of Virginia, Richmond, Virginia, 23298, U.S.A.

Department of Toxicology, Swedish Medical Research Council, Karolinska Institutet, S-10401 Stookholm, Sweden.

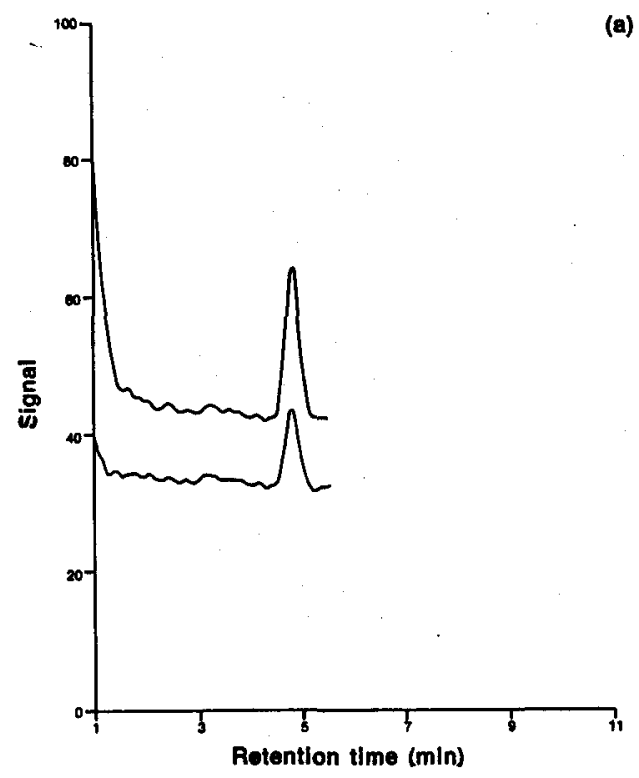

(a)

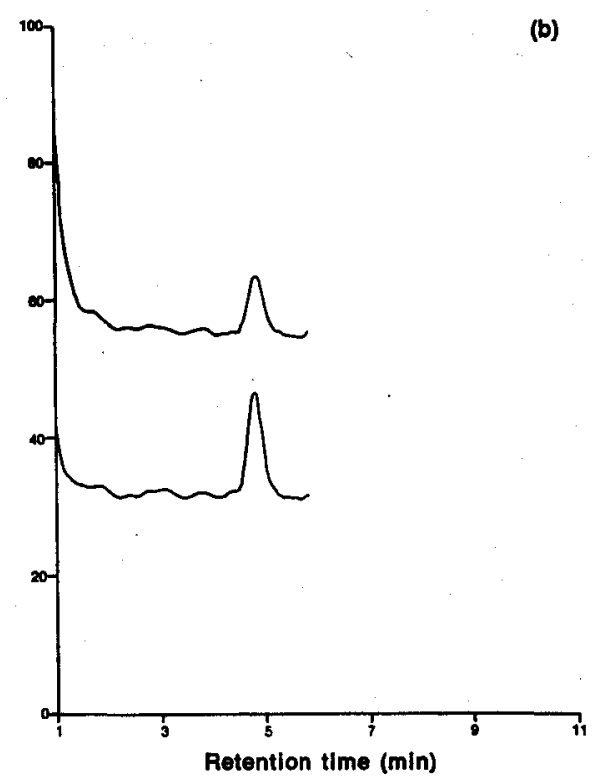

Figure I. Mase fragmentogram of extract of plasma from unokere with deuterated nicotine as added Internal standard.
The upper and lower traces represent $\mathrm{m} / \mathrm{e} 84$ (nicotine) and $\mathrm{m} / \mathrm{e} 86$ (deuterated nicotine) ion current respectively; the left hand part of the figure gives date for the first smoker (95 $\mathrm{ng} / \mathrm{ml})$ and the right hand part is for the second (26 $\mathrm{ng} / \mathrm{ml})$.

Figures 1 to 30 are shown on pages 346 to 349 . 
Figure 1a. Mass spectrum of S-(-)-nicotine (la).

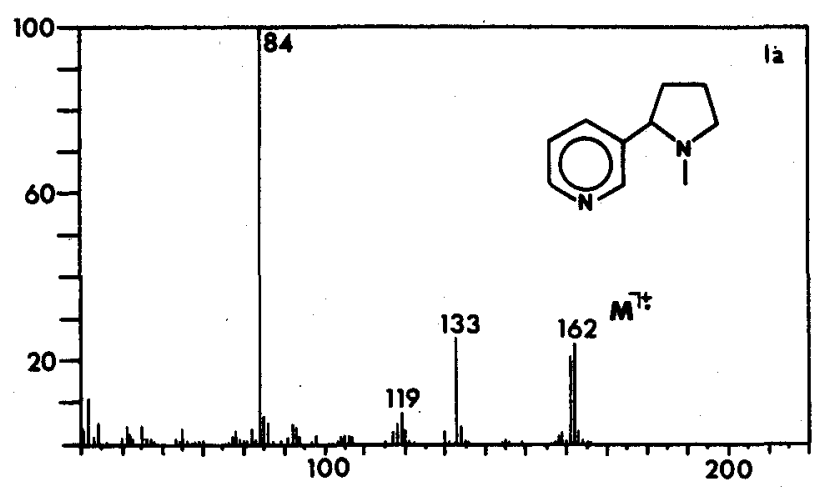

Flgure 1b. Mass spectrum of 5-dz-S-(-)-nlcotine (lb).

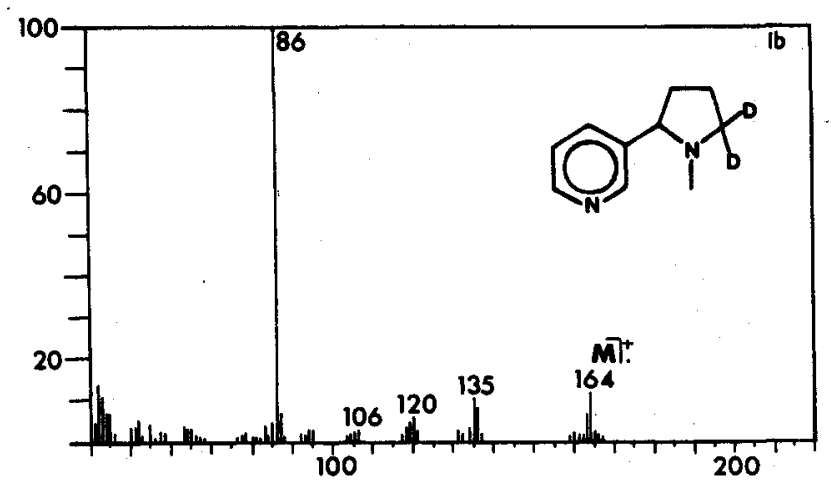

Flgure 2. Mase spectrum of S-(-)-nlcotine lsomethlodide hydrolodide (II).

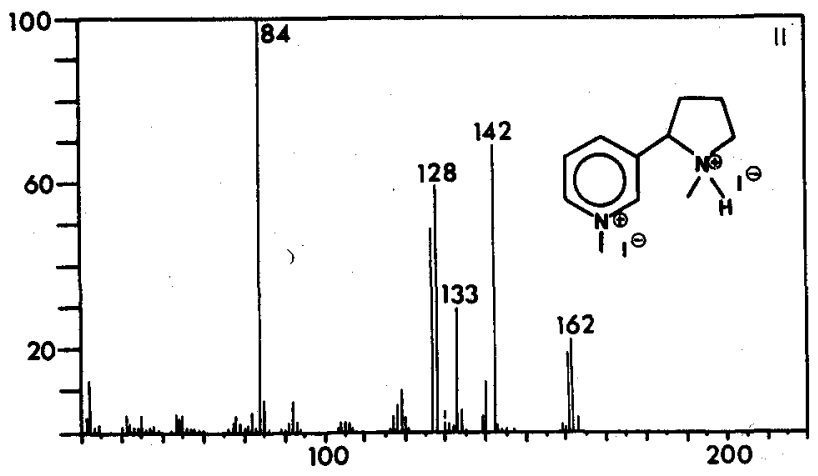

Figure 3a. Mass spectrum of S-(-)-nicotine-1'-oxide (III) (dlrect probe).

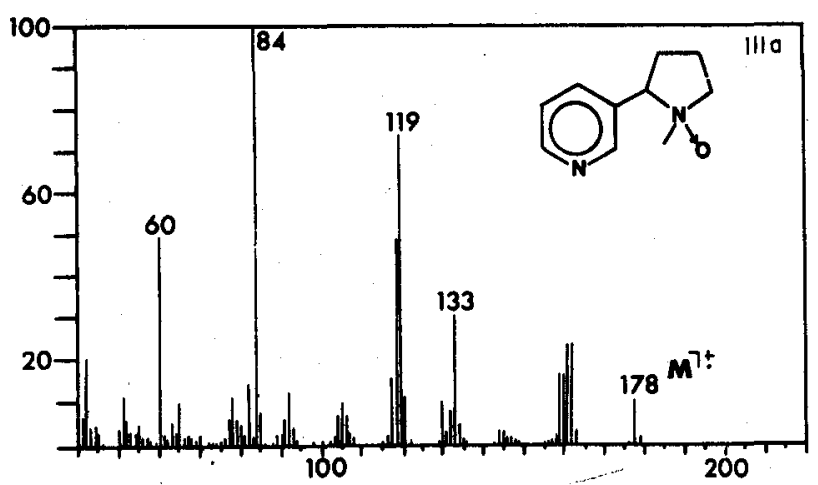

Figure 3b. Mase epectrum of S-(-)-nlcotine-1'-oxide (III) (GC-MS).

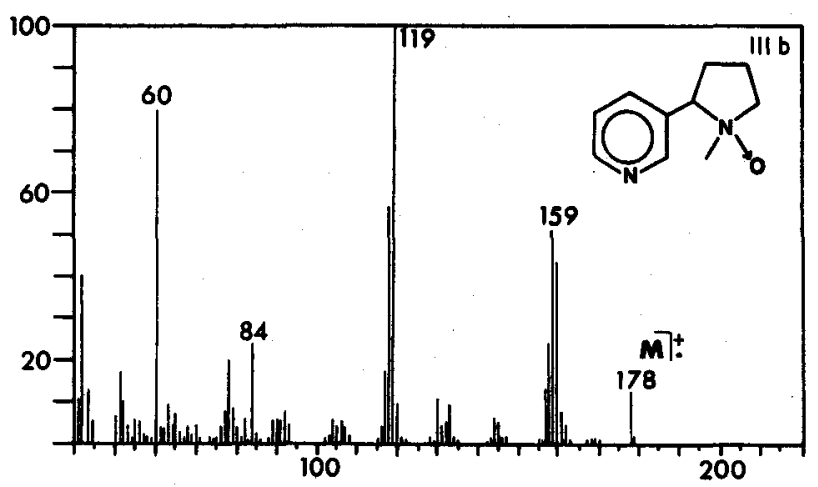

Figure 4. Mass spectrum of 5-(-)-nicotine-1,1'-dioxide (IV).

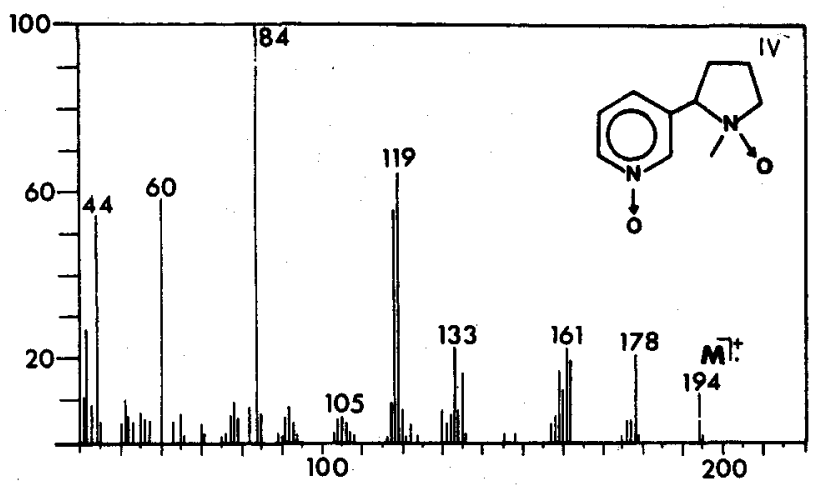

Figure 5. Mass spectrum of S-(-)-nornicotine (V).

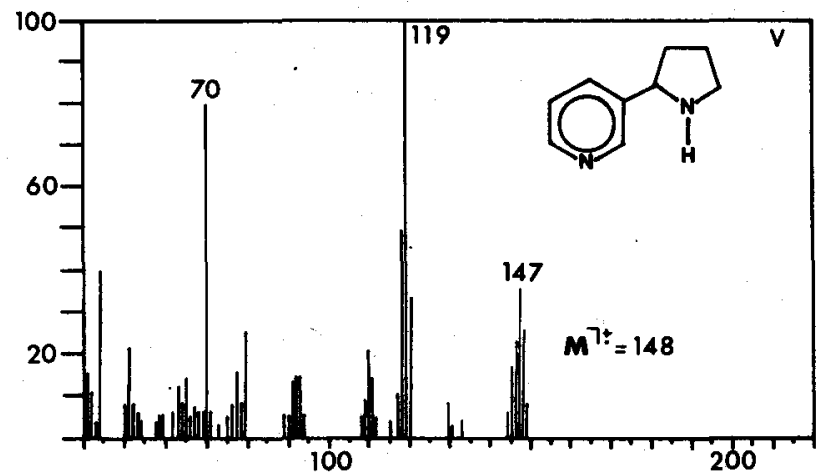

Figure 6. Mass spectrum of myosmine (VI).

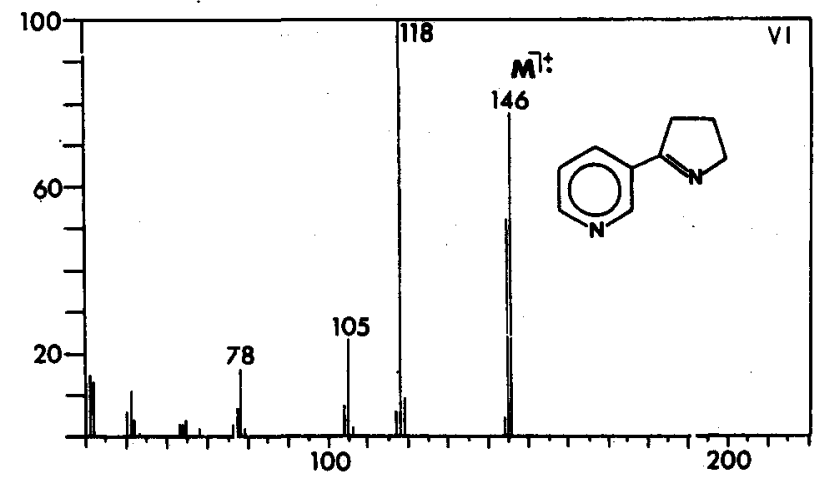


Figure 7. Mass spectrum of $\beta$-nicotyrine (VII).

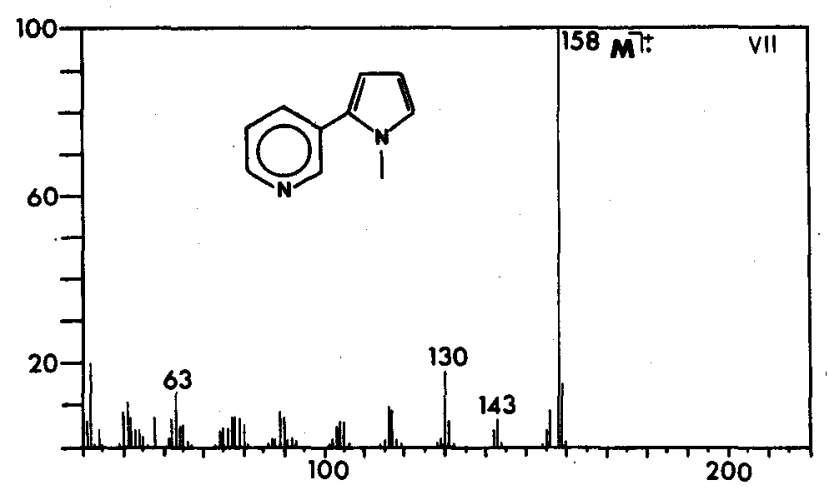

Flgure 8. Mass spectrum of S-(-)-anabasine (VIII).

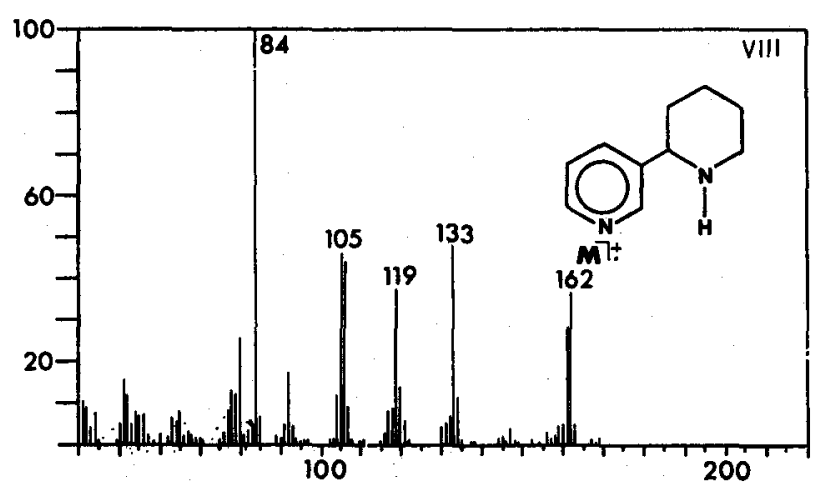

Flgure 9. Mass spectrum of S-(-)-methylanabasine (IX).

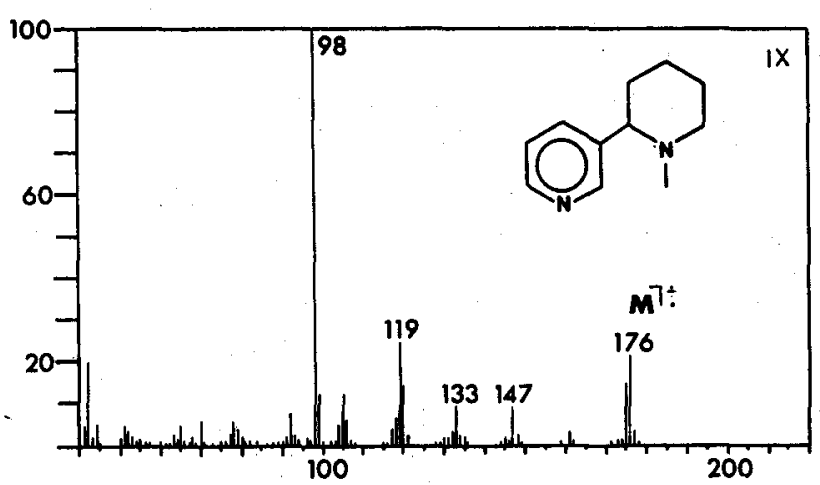

Flgure 10. Mass spectrum of S-(-)-cotinine (X).

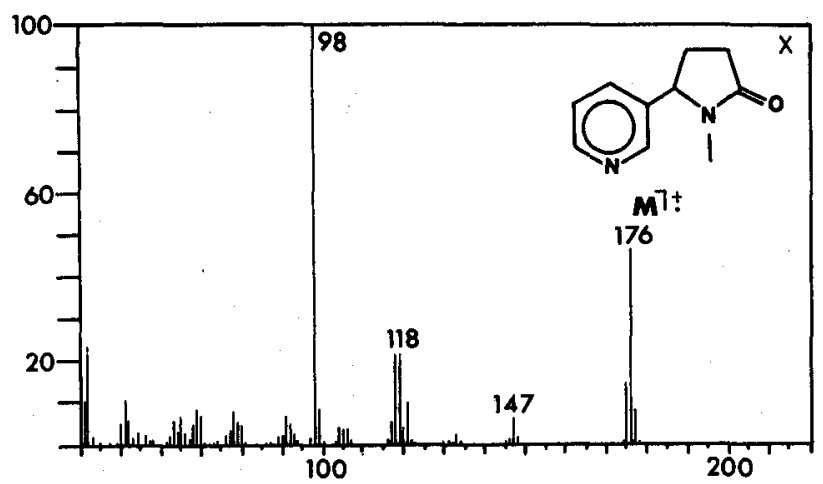

Flgure 11. Mass spectrum of S-(-)-cotinine methiodide (XI).

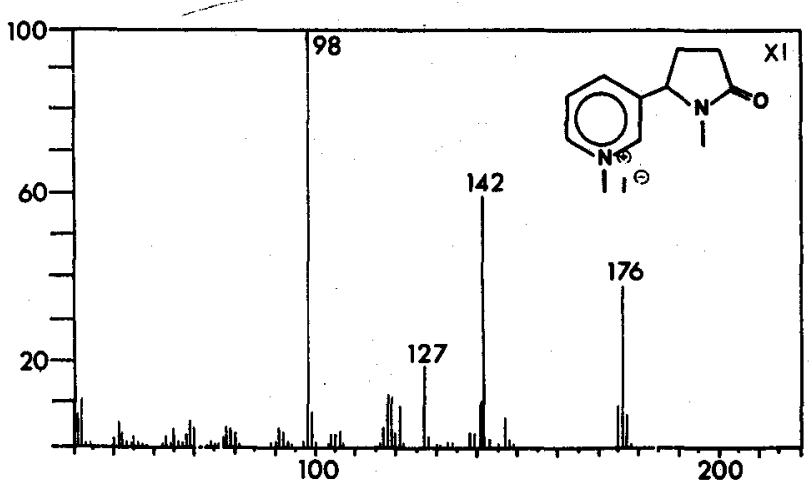

Figure 12. Mass spectrum of S-(-)-cotinine-1-oxide (XII).

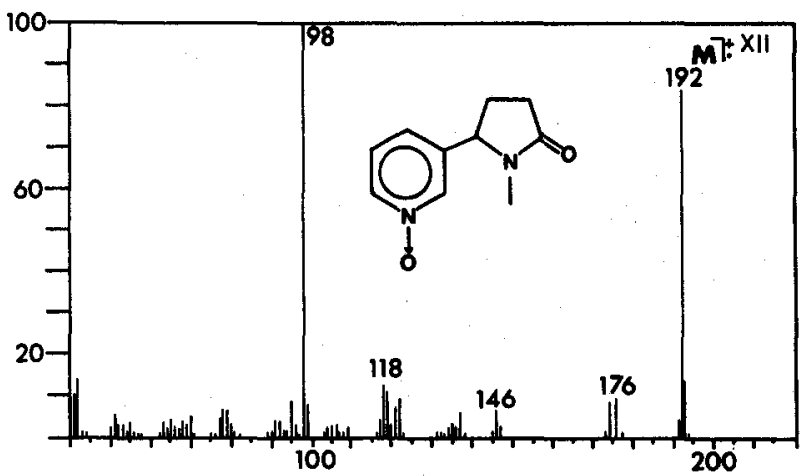

Figure 13. Mass spectrum of 8-(-)-norcotinine (XIII).

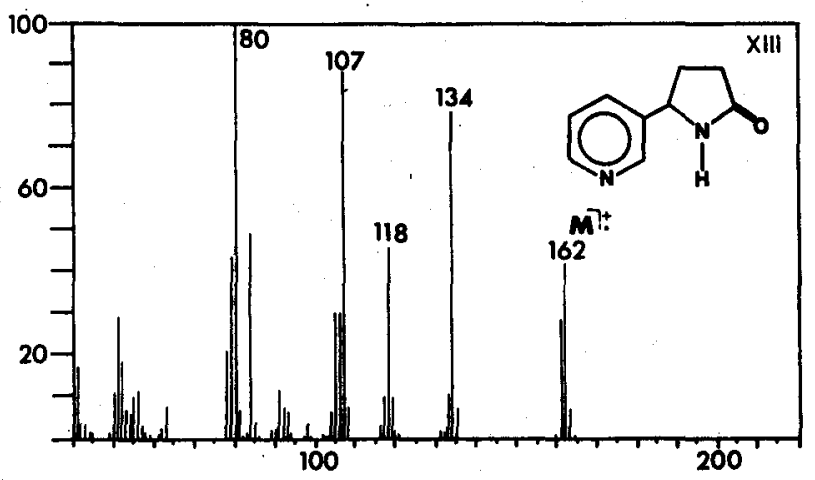

Figure 14. Mass spectrum of (5S,3R)-3-hydroxycotinine (XIV).

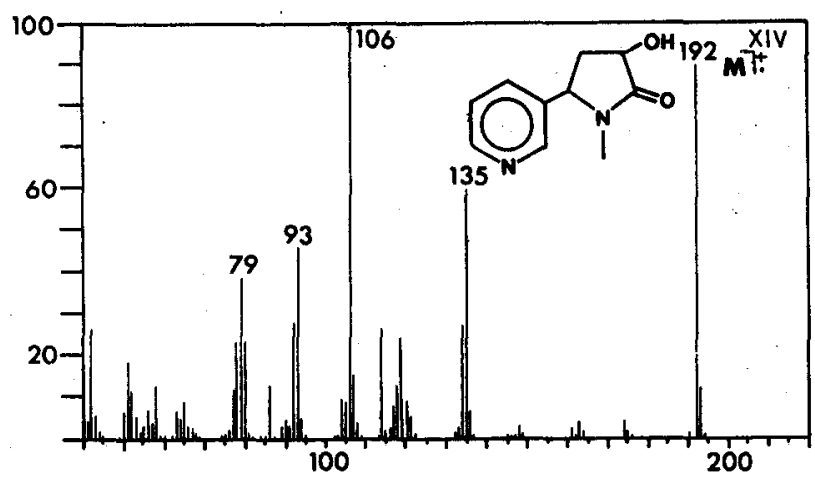


Figure 15. Mass spectrum of dihydrometanicotine (XV).

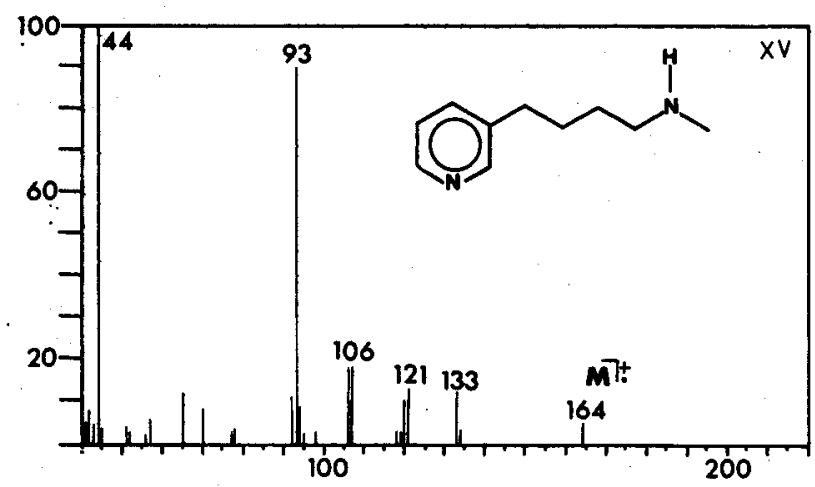

Figure 16. Mass spectrum of trane-metanicotine (XVI).

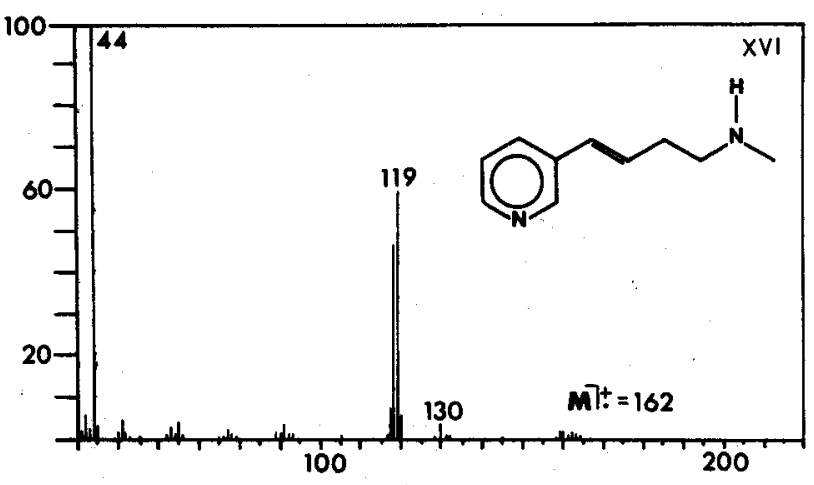

Figure 17. Mass spectrum of cis-metanicotine (XVII).

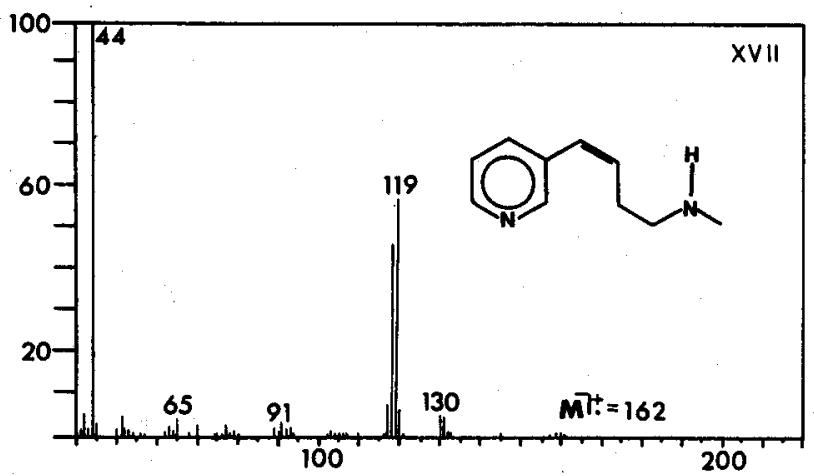

Figure 18. Mass spectrum of 4-(3-pyridyl)butyric acid (XVIII).

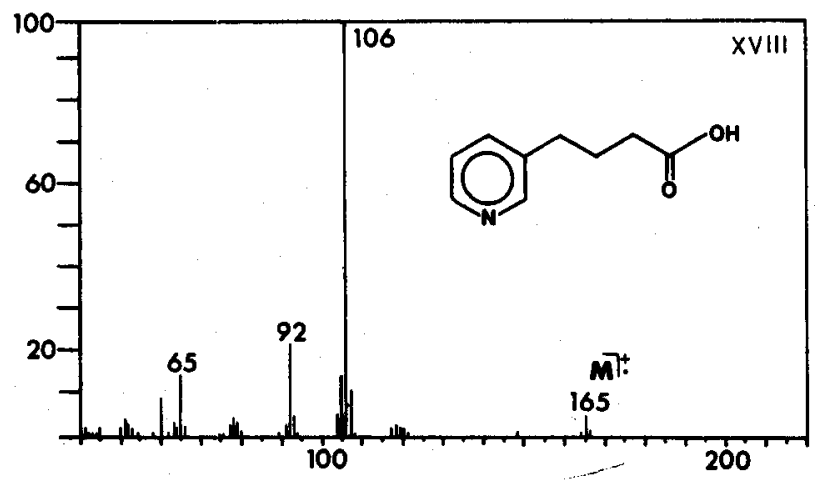

Figure 19. Mass spectrum of methyl 4-(3-pyridyl)butyrate (XIX).

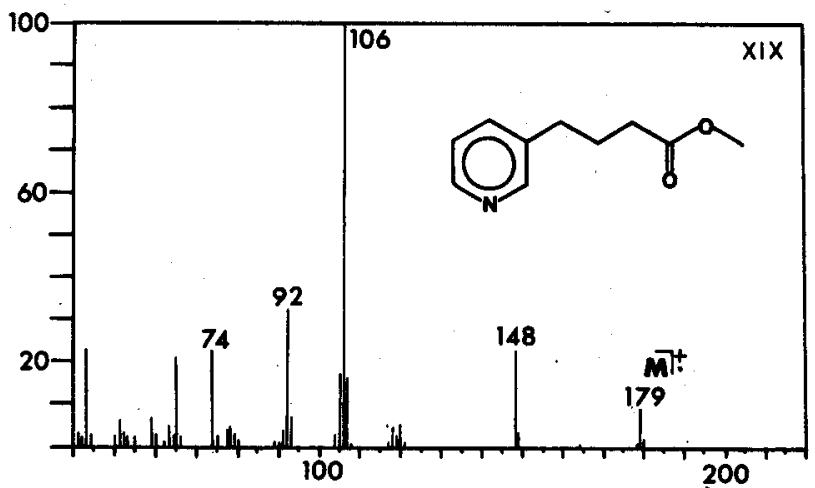

Figure 20. Mass spectrum of 4-(3-pyridyl)-4-oxobutyric acid (XX).

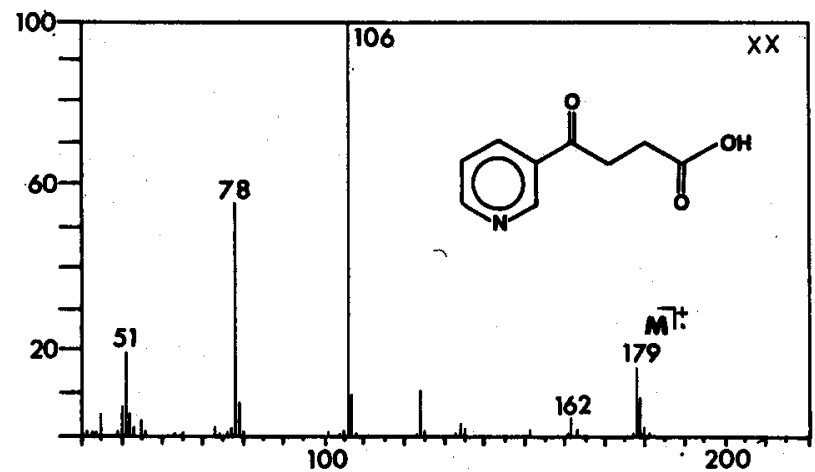

Figure 21. Mass spectrum of mothyl 4-(3-pyridyl)-4-oxobutyrate (XXI).

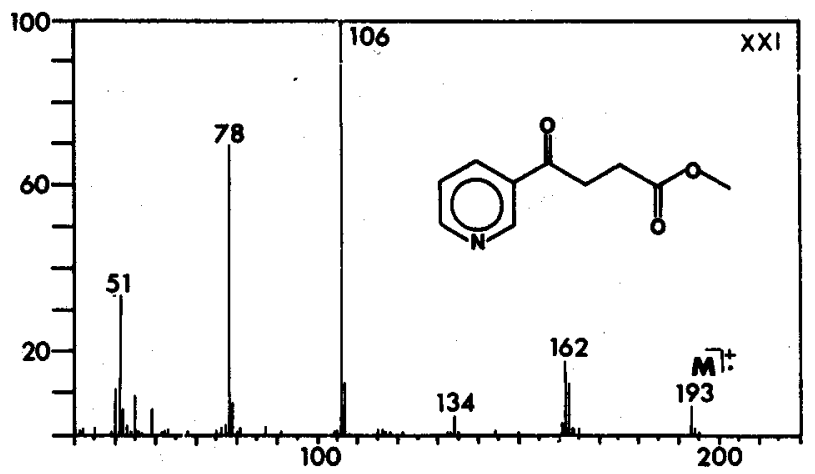

Figure 22. Mass spectrum of 4-(3-pyridyl)-4-hydroxybutyrle acid (XXII).

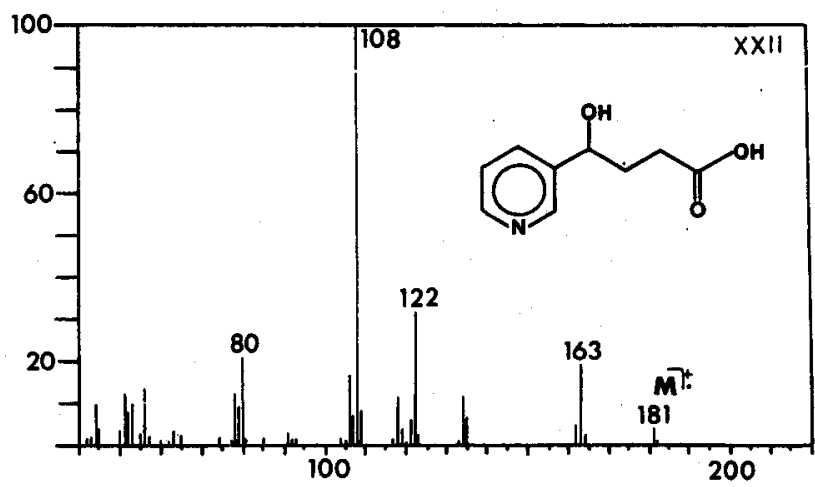


Figure 23. Mass spectrum of methyl 4-(3-pyrldyl)-4-hydroxybutyrate (XXIII).

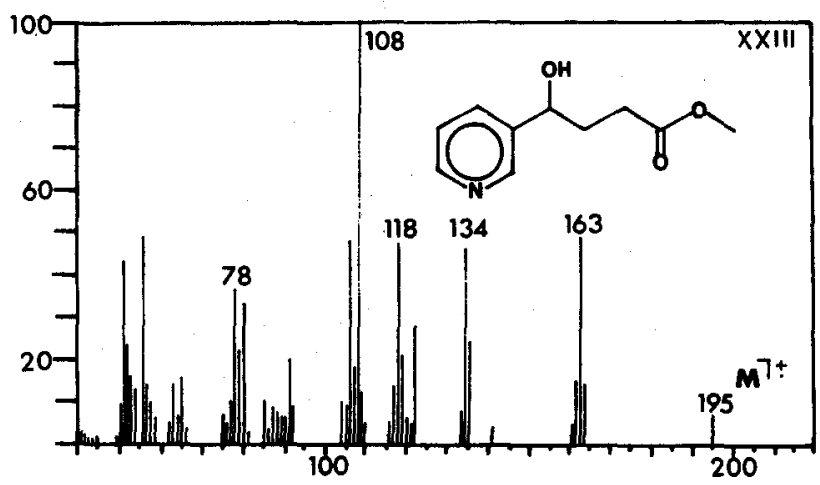

Figure 24. Mass spectrum of 5-(3-pyridyl)tetrahydrofuran-2one (XXIV).

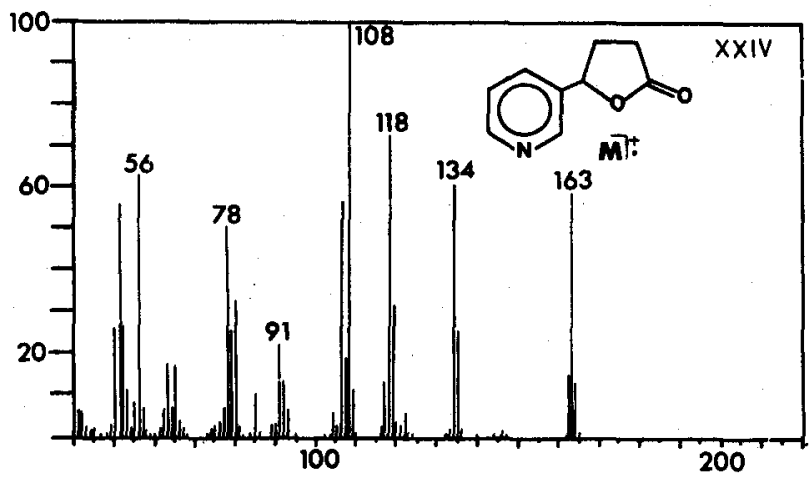

Figure 25. Mass spectrum of 4-(3-pyridyl)-4-oxobutyramide (XXY).

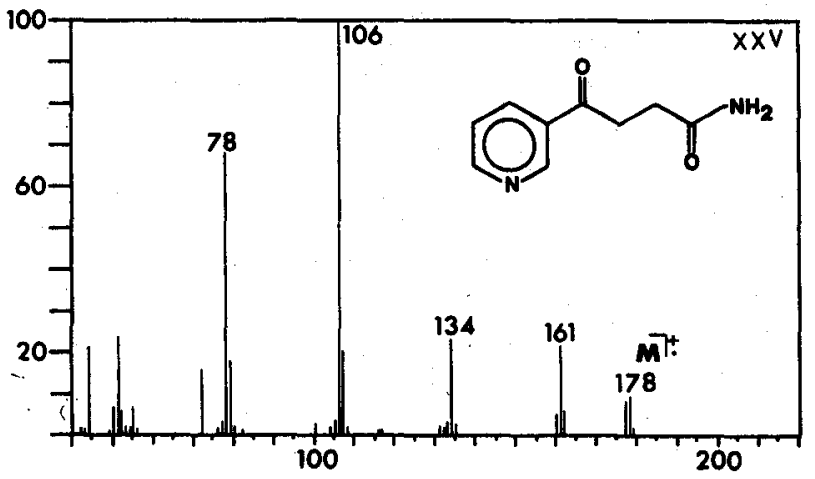

Figure 26. Mass spectrum of allohydroxycotinine (XXVI).

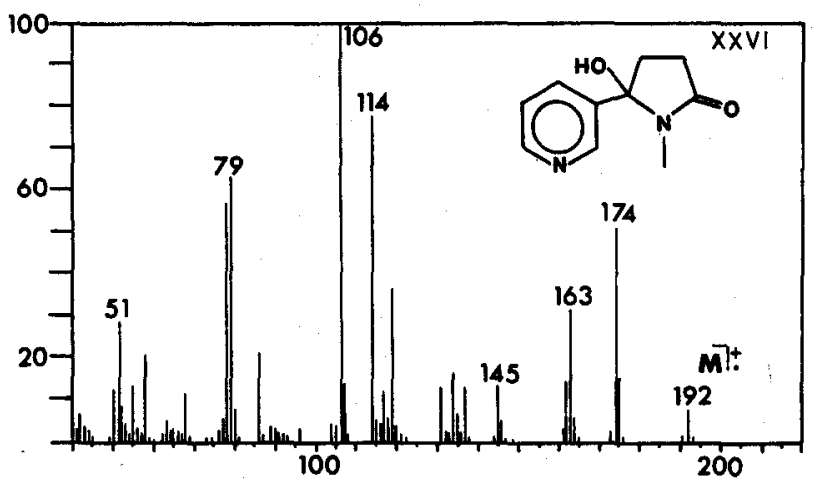

Figure 27. Mass spectrum of 3-pyridylacetic acld (XXVII).

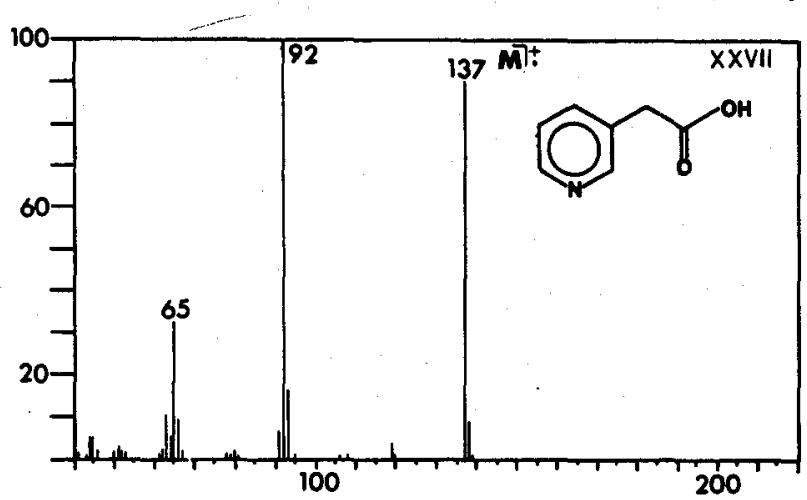

Figure 28. Mass spectrum of methyl 3-pyrldylacetate

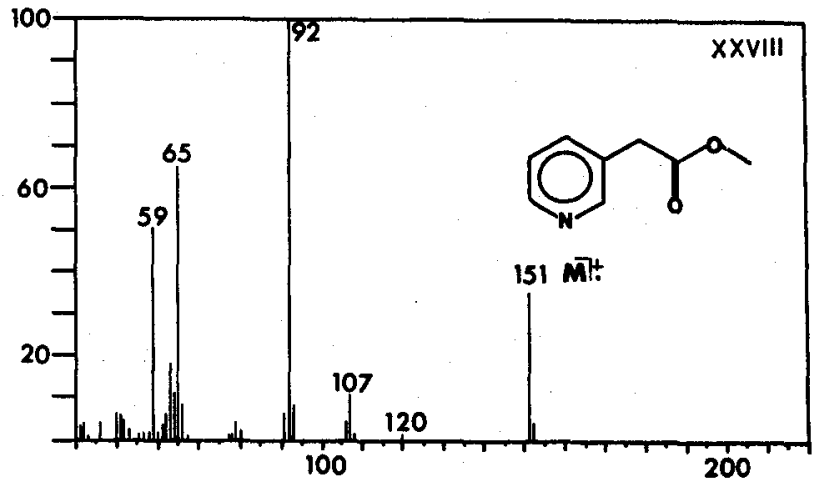

Figure 29. Maes epectrum of N-(3-pyridylacetyl)glycine (XXIX).

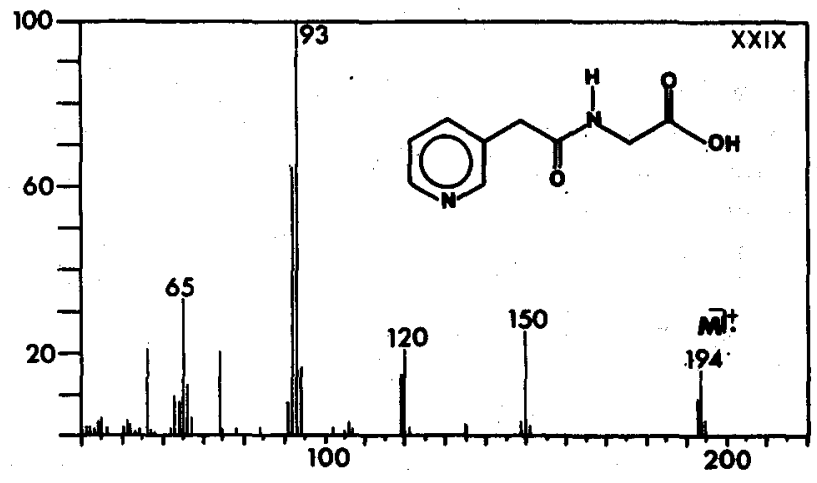

Figure 30. Mass spectrum of methyl N-(3-pyridylacetyl)glyclnate $(\mathbf{X X X})$.

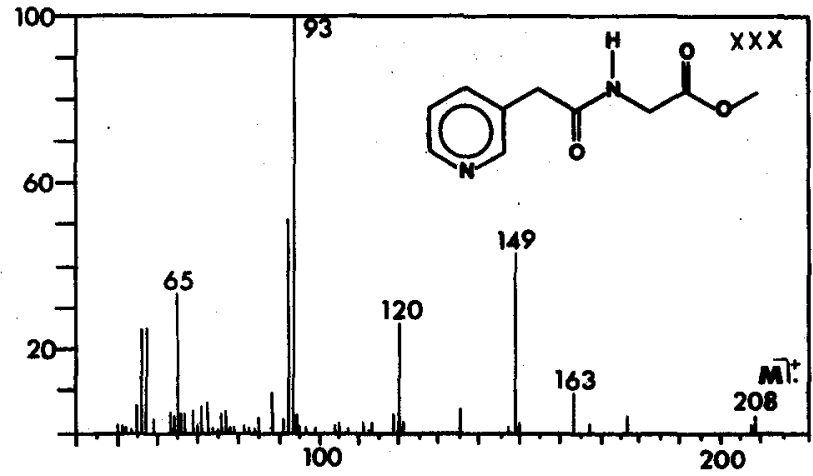

